\title{
Land Use and Agriculture: Pitfalls and Precautions on the Road to Net Zero
}

\author{
Dave S. Reay ${ }^{* t}$ \\ School of Geosciences, The University of Edinburgh, Edinburgh, United Kingdom
}

Land use is a crucial sector in delivering enhanced carbon sequestration globally. At the same time food production is a major source of global greenhouse gas emissions. As pressure mounts for all nations to increase their levels of ambition under the Paris Climate Agreement, so the pressure to radically reduce emissions from the agriculture sector and enhance carbon sequestration in the land use sector also ramps up. This trend is most clearly evident in the drive for "net zero" where unavoidable emissions, such as those from food production, are balanced by more sequestration via land use change. Here we examine some of the major risks, applicable safeguards, and potential pathways for

OPEN ACCESS

Edited by:

Barbara Olfe-Kraeutlein, Institute for Advanced Sustainability

Studies (IASS), Germany

Reviewed by:

Rafael Mattos Dos Santos, University of Guelph, Canada

José Luis Vicente-Vicente,

Leibniz Center for Agricultural

Landscape Research

(ZALF), Germany

${ }^{*}$ Correspondence:

Dave S. Reay

david.reay@ed.ac.uk

tORCID:

Dave Reay

orcid.org/0000-0001-8764-3495

Specialty section:

This article was submitted to Negative Emission Technologies,

a section of the journal

Frontiers in Climate

Received: 05 February 2020

Accepted: 29 June 2020

Published: 04 August 2020

Citation:

Reay DS (2020) Land Use and Agriculture: Pitfalls and Precautions on the Road to Net Zero. Front. Clim. 2:4.

doi: 10.3389/fclim.2020.00004 agriculture and land use in realizing net zero. Using the UK as an example we highlight the importance of governance, finance, skills, research and technology, and society in this transition. We conclude that successful land use policy for net zero will require extremely demanding levels of integration and spatial resolution, and that the research community has a vital role to play in providing a robust evidence base for this. We also invoke the Cancun safeguards as a basis on which a more sustainable and just transition to net zero might be based. Finally, we warn of unintended distortions to policy and markets if the drive for net zero is too blinkered.

Keywords: afforestation, peatlands, soil carbon (C) sequestration, carbon sequestration, rural policy design

\section{INTRODUCTION}

Our global food system is now responsible for around one-quarter of anthropogenic greenhouse gas emissions, with agricultural production the dominant source of these emissions (Vermeulen et al., 2012). As human population expands and diets become more meat and dairy intensive, so emissions will rise further unless substantial changes in food production and supply are realized (Tilman and Clark, 2014). The Paris Climate Agreement aims to limit global average temperature increase to well below $2^{\circ} \mathrm{C}$ above the pre-industrial baseline and pursue efforts to keep warming within $1.5^{\circ} \mathrm{C}$. Achieving this goal will require net global $\mathrm{CO}_{2}$ emissions to reduce to zero by the middle of the century (Rogelj et al., 2018). Some developed nations, such as the UK, have now committed to a target of "net zero" for all greenhouse gases (GHGs) by 2050-whereby unavoidable emissions are balanced by increased domestic sequestration. Without major reductions in emissions from agriculture alongside substantial increases in sequestration such national targets become near impossible. As such, our agriculture and land use sectors face a fiendishly difficult balancing act of ensuring sufficient quantity and quality of food, lower emissions, increased sequestration, protection of natural ecosystems, soil, water, and air quality, and all in the context of a climate that is already changing (Seddon et al., 2020). The prize for humanity of achieving this balance is huge, but the potential pitfalls of "carbon blinkered" rural policy to deliver net zero are enormous. Here we discuss some of the key issues that must be addressed, safeguards 
that should be put in place, and some of the mechanisms that can deliver a sustainable net zero future for land use. We include examination of "conventional" carbon sequestration strategies, such as on-farm woodland and managed soil C enhancement, as well as emerging approaches such as BECCS (Biomass Energy with Carbon Capture and Storage), biochar and enhanced weathering. All have high relevance to the agriculture and land use sectors, but also significant risks in terms unintended consequences.

We focus on the UK as a developed nation with a legallybinding target of net zero GHG emissions by 2050 and where development of new farming policy to support "public goods" like climate change mitigation is already a focus due to exit from the EU's Common Agricultural Policy (Bateman and Balmford, 2018). Here, the transition to net zero is set to rely heavily on changes in domestic land use and agriculture, potentially delivering greenhouse gas emissions savings of over $40 \mathrm{Mt} \mathrm{CO}_{2} \mathrm{e}$ per year by 2050 (compared to today) and including forestry $(\sim 14 \mathrm{Mt})$, low carbon farming practices $(\sim 10 \mathrm{MT})$, dietary change and food waste $(\sim 7 \mathrm{Mt})$, agroforestry $(\sim 6 \mathrm{Mt})$, peatlands ( $\sim 5 \mathrm{Mt})$ and energy crops ( 2 Mt) (CCC, 2020).

\section{LAND USE AND NET ZERO IN THE UK}

The UK's net zero by 2050 target requires an estimated $20 \%$ of current agricultural land be repurposed to increase forest cover, bioenergy production, peatland restoration and overall land use diversification (CCC, 2019). The prime strategy put forward to allow such a large release of existing agricultural land is that of increased efficiency of food production-enhanced productivity in some areas allowing land sparing and the use of these other land areas for climate change mitigation (Lamb et al., 2016).

To incentivise such release of land to meet non-food aims (rather than simply to try and enhance production in all areas), the opportunity costs of a change to non-food land use must be met (Bustamante et al., 2014)—often referred to as "income foregone" (Barnes et al., 2011). In principle this mechanism allows governments to manage levels of domestic food selfsufficiency while also allowing enhanced action on their key nonfood objectives, such as climate change mitigation. In reality, setting an effective "income foregone" price point that avoids unintended consequences, like falls in domestic food security and increased reliance on imports, can be very difficult. Even where land sparing occurs, it does not inevitably mean greater public goods are then delivered. The spared land might not end up in the aimed-for alternative use, or the desired performance of the spared land in delivering public goods may not be met (Balmford et al., 2019).

Fundamental to successful delivery of such complex transformations will be a well-integrated decision support system for rural policy that takes account of potential for food production alongside greenhouse gas (GHG) mitigation, C sequestration, biodiversity protection, livelihoods, water and air quality, climate resilience and the host of other demands placed on our land (Helm et al., 2020). Clearly, for any nation aiming to achieve net zero there are multiple trade-offs to be made within a limited land area, and big risks if local socioeconomic contexts are not well-integrated with national science-based targets (Dooley and Kartha, 2018).

\section{NET ZERO PITFALLS}

The planned transition in UK land use to achieve net zero is both rapid and far-reaching, making the risk of unintended consequences policy outcomes especially high. A "just transition," whereby the sustainability of land use change, livelihoods and support mechanisms is ensured, is crucial to avoiding pitfalls ranging from clashes with other national and international frameworks, through erosion of rural communities and cultures, to complete reversal of $\mathrm{C}$ sequestration and off-shoring of emissions.

Firstly, future rural policy for net zero at a national level would need to complement or be consistent with overlapping national programmes and relevant international agreements. On the latter, "net zero GHG by 2050" for developed economies is deemed consistent with the Paris Climate Goals (CCC, 2019), but any land use actions to deliver it would also need to consider synergies and antagonisms with international agreements such as the UN Convention on Biodiversity (CBD) and the UN Sustainable Development Goals (SDGs) (Smith R. et al., 2019).

Governance of a net zero transition must likewise take full account of national and sub-national legislation and powers. For example, land use change in Scotland is likely to deliver a significant proportion of the $\mathrm{C}$ sequestration required for the whole of the UK by 2050 (Alcalde et al., 2018; CCC, 2019). The risk here is that misaligned constitutional competencies lead to sub-national mitigation being hindered, with aggregate national targets then being missed.

\section{Permanence}

Ultimately the success of a net zero transition is measured by its sustainability and the negative impacts of climate change that it prevents. Where changes in land use to enhance $\mathrm{C}$ sequestration are only short-term (a few years or decades) and are then reversed, the benefits in terms of reduced climate change impacts may be negligible (Kirschbaum, 2006). This "permanence" issue should therefore be a fundamental consideration in future support systems. Current financial support for such agricultural land use change in the UK is commonly for 5-10 years, with a requirement that new woodland remains in place for 20 years (Commission, 2019). Likewise, though soil C this can be enhanced in some areas through changed farming practices (e.g., minimum tillage) or changed land use (e.g., woodland creation) any particular enhancement is both limited and reversible. For highly degraded soils the gains in soil $\mathrm{C}$ through changed land use may initially be very rapid, but in all systems an equilibrium level will eventually be reached and subsequent return to cultivation can then mean rapid loss of stored $\mathrm{C}$ to the atmosphere.

Any enhanced $\mathrm{C}$ sequestration achieved may therefore be short-lived as land is converted back to its original use once funding and contractual obligations have expired. While the design of future land use support systems could help mitigate such permanence risks, there are aligned policy 
approaches that may provide even more sequestration security. Direct linkage of enhanced timber production with building construction could, for instance, greatly extend the magnitude and average lifetime of sequestered $\mathrm{C}$-high use of timber in urban building construction could store up to 0.68 GTC $y^{-1}$ globally (Churkina et al., 2020).

Soil amendments, such as biochar or the use of basic and ultrabasic minerals for enhanced weathering, also have the potential to provide much longer lifetimes for $\mathrm{C}$ sequestration in the land use sector, though with significant barriers to large scale implementation in sourcing of sustainable feedstocks, costs, and land availability (Alcalde et al., 2018).

Finally, combustion of biomass for energy and capture and geological storage of the associated $\mathrm{CO}_{2}$ (Biomass Energy with Carbon Capture and Storage, BECCS), promises very long term (multi-millennial) $\mathrm{C}$ storage and so could play a very large role in future land use strategies to achieve net zero (Azar et al., 2010). Again, unsustainable feedstock sources, high costs, and limited land availability represent significant barriers to successful implementation (Fajardy and Mac Dowell, 2017; Harper et al., 2018).

\section{Leakage}

Like permanence, the issue of "leakage" is one that has already challenged many land use change policies designed to help mitigate climate change (Schwarze et al., 2002). Here, emissions reductions or enhanced sequestration in one place are partly or wholly offset by increased emissions elsewhereforest protection one area leading to increased deforestation in another for instance. At national scales such leakage results in effective offshoring of a nation's reported emissions as these are reported to the UNFCCC on a production (rather than consumption) basis.

Were new land use and agriculture support policies to align with net zero ambitions in a way that reduced national food self-sufficiency, and so raised food imports, then such offshoring of emissions would be highly likely. One illustration of these risks for the UK is in the expansion of commercial forestry. As described previously, expansion of forestry combined with increased use of timber for construction offers a way to address some of the permanence issues inherent in land-based climate mitigation policies. For the UK such a transition could mitigate over 2 tons $\mathrm{CO}_{2} \mathrm{e} \mathrm{ha}{ }^{-1}$ over a 100 year time horizon. However, the effective mitigation per hectare of forest could be halved if this forest expansion resulted in displacement of UK beef production to Brazil (Forster et al., 2019).

Another recently highlighted example of such risks is that of a 100\% conversion to organic food production in England and Wales. Under such a scenario, domestic food production and production-based emissions estimates would fall, but overseas emissions (including those due to land use change) could rise to an extent that would more than offset any of the emission reductions seen in England and Wales (Smith L. G. et al., 2019).

Leakage is therefore of major importance for agriculture and land use in the context of global net zero ambitions as it can entirely undermine the global efficacy of national actions to tackle climate change (de Ruiter et al., 2016).

\section{REALIZING NET ZERO}

\section{Governance}

For the UK, indeed for all nations, important lessons can be learned from existing international frameworks relating to land use. The UN's REDD (Reduced Emissions from Deforestation and Degradation) programme and in particular its "Cancun Safeguards" (Chhatre et al., 2012) provide an exemplar of efforts to balance multiple competing needs within a finite land area. Though developed with forestry in mind, these safeguards-such as transparent and effective governance-could usefully align with wider rural policy development as nations like the UK strive to deliver net zero alongside a multitude of other goals.

Transparent and effective land use governance for net zero could not only help avoid unintended consequences of policy changes, they would also help to ensure that aggregate change remains compatible with targets. To give alignment with international and national commitments, the balancing of natural ecosystem and biodiversity protection with net zero and food production goals must be overtly integrated within rural policy development, support and MRV (Monitoring, Reporting, and Verification). Past on-farm mitigation or woodland planting schemes, for instance, may well have provided multiple "public goods," but the evidence base for these is badly lacking (Burton et al., 2018).

Independent advice on emission reduction targets and pathways is a central plank of any sustainable strategy to deliver net zero. In this, the UK's Committee on Climate Change already serves a vital role in advising government and monitoring progress at a UK-wide level and at a devolved administration level (McGregor et al., 2012). This has allowed integration of national and sub-national targets along with a consistent use of the evidence base. However, the co-dependency of UK and devolved administration climate targets means policy development and implementation must be well-integrated too. To avoid a cross-border blame game of shortfalls and delays, governance and delivery of the UK's regionally-biased demands on land use for net zero will therefore need to tread a careful line to ensure transparency is maintained and that the competencies and circumstances of the devolved administrations are respected.

\section{Finance}

Effective financial support systems will be fundamental to realizing net zero via land use change. These could be adaptations of existing systems (like revised CAP payments) (Matthews, 2013), newly developed ones directly targeted at public goods (e.g., the UK's Agriculture Bill and its ELM scheme; Rayment, 2019; Rodgers, 2019), or more market-led climate change-specific approaches such as carbon pricing and offsets (Crossman et al., 2011). Each has its strengths and weaknesses.

For revision of the EU's Common Agricultural Policy (CAP), a strength could be its proposed "Eco-scheme" which would allow member states more latitude to align subsidies with net zero objectives and so drive more rapid change. The potential weakness here is that that same latitude is used to water down climate change action in the agriculture sector for nations 
where short-term political pressures or climate-skeptic ideologies prevail (Dupraz and Guyomard, 2019).

For the "Environmental Land Management" (ELM) scheme proposed as part of post-CAP support in England, there are significant strengths in the overt linkage of climate change mitigation and resilience to future support-allowing government to much more directly incentivise both emissions reductions and $\mathrm{C}$ sequestration in the agriculture and land use sectors. Key potential weaknesses again include the danger that political pressures distort incentive levels and focus. There also remain major questions around how such an ELM support scheme would reliably calculate the correct price points for specific actions, and indeed whether it is actions that should rewarded or the outcomes of these actions (Rayment, 2019).

On carbon pricing and offsets, such market-based mechanisms to incentivise land use that aligns with net zero have the significant advantage that they rely less (or not at all) on public funds and can in theory deliver the most cost effective land-based mitigation or $\mathrm{C}$ sequestration for any particular area or land owner. However, as evidenced by existing carbon markets, too low a carbon price can stymie activity (Wood and Jotzo, 2011) and so a carbon price floor or guarantee (as currently offered for woodland planting schemes in England for example; Government, 2019) may then be required. This price intervention then inevitably poses the risks of unintended market distortions and a greater reliance on public funds.

All of the above could also exacerbate leakage issues due to financial incentives that overvalue, say, tree planting at the expense of food production or "permanence" issues due to incentives having short lifetimes or weak assurance mechanisms for upkeep of the change in land use. Unintended market distortions such as offshoring of emissions could be limited through modeling of consumption-based emissions effects and tailoring of incentive type, magnitude and timing to better forecast and align changes in domestic food production with changes in domestic demand and global markets.

Clearly, well-directed financial incentives can simultaneously provide substantial emission reductions, $\mathrm{C}$ sequestration and climate resilience in the land use sector. A crucial aspect of such incentives in helping to deliver net zero aims will be creating a support system that is nuanced enough to lead to the best land management changes within local contexts while still being attuned to transboundary (e.g., leakage) and temporal (e.g., permanence) safeguarding.

\section{Skills}

Financial support for achieving net zero is only useful if it is accessible. Land managers will need support in aligning practices with any new suite of mitigation and sequestration options available for their circumstances. They will also need assistance with how to meet any mandatory compliance checks and MRV requirements. For many, training in new skills (e.g., silviculture and agroforestry practices) will be required, while others may need assistance with best application of new technologies and practices (e.g., drone technology, farm nutrient budgeting and animal health improvements) (Feliciano et al., 2014).
Net zero capacity-building in the agriculture sector could be supported by a more comprehensive version of existing extension services, perhaps aligned to improved digital learning resources (Feliciano et al., 2017). It is also likely to require new service providers to either advise on, or provide directly, specific elements of net zero-aligned rural support. Commercial companies already provide a swathe of agricultural testing, equipment and advisory services. As specific elements of new rural support regimes become clear, so the private sector can be expected to respond to changing needs and demands. For instance, field-scale soil carbon testing may well become a requirement for farms wishing to access new subsidy payments. A certain level of such testing might be covered by publiclyfunded extension services, but commercial testing, modeling and on-farm soil C estimation tools (Malone et al., 2017) are likely to play a major role in allowing all farmers to meet future MRV requirements (Smith et al., 2020).

Crucially, farm-level decision support tools would also need to be further developed to support new practices at locallyrelevant scales across the UK. There is already a plethora of such tools, but engagement rates are generally low (Rose et al., 2016). Direct integration with new rural support systems, combined with greater usability, is therefore required.

Existing or emerging extension service providers would themselves need significant new training and resources in order to deliver to such emerging decision support and MRV needs. More widely there is a need for formal educational providers, such as Further and Higher Education Institutions, to align their provision with economy-wide net zero goals (Allan et al., 2020), including those relating to land use and agriculture. Part of this alignment could arise from a deliberate refocus of state-funding for courses and student places, while much could be driven by student demand and the rapid expansion in land use sector job opportunities and skills needs that a sustainable net zero transition represents.

\section{Research and Development}

A robust evidence base for changes in rural policy is a further prerequisite for net zero. However, this research base is far from complete. New technologies, along with improved data availability and fast-changing energy systems, can certainly become powerful facilitators of a net zero pathway for land use and agriculture. Precision agriculture, for example (including drone technology, machine guidance, and field-based sensors), has developed apace and is already commercially viable for many of the larger arable farms in the developed world (Balafoutis et al., 2017). However there remain issues of accessibility to these and other technologies that could improve productivity for many farms and so enhance overall land sparing for sequestration (Long et al., 2016).

For large scale land-use dependent mitigation strategies, such as BECCS, there are significant research questions still to answer in terms of sustainable feedstock types and sources, land suitability and availability, risks to biodiversity and supporting infrastructure requirements (Donnison et al., 2020). Likewise for many of the proposed on-farm mitigation strategies that could contribute to net zero targets (Lampkin et al., 2019), such as 
slurry storage and application (Amon et al., 2006; Misselbrook et al., 2016), livestock breeding and feed additives (Wall et al., 2010; Gerber et al., 2013), soil and fertilizer amendments (Cayuela et al., 2014), and altered land management (Powlson et al., 2014; Garnett et al., 2017), there are uncertainties in terms of efficacy under different site conditions and potential negative side effects of implementation. For example, nitrification inhibitors offer significant potential to reduce $\mathrm{N}_{2} \mathrm{O}$ emissions from nitrogen fertilizer application, yet they may also increase $\mathrm{NH}_{3}$ emissions (Soares et al., 2012) and so swap a climate change penalty for an air quality and biodiversity one.

Aligned to the need for a robust evidence base for land-based mitigation decisions at local scales is that of risk and resilience assessments (Sample et al., 2016). These, such as to account for changing climate, invasive species, and pest and disease risks, also require a degree of spatial and temporal resolution that is meaningful at farm scales. In the UK, the UKCP09 and UKCP18 climate projection products provide a good basis for this (Brown et al., 2011), but translation, downscaling and integration of such information into an effective decision support system for land users still requires a significant effort from research providers and advisors.

Crucially, extensive social, ecological, and economic research is needed to complement and challenge assessments of technical feasibility. The kinds of rapid and large scale changes in land use that are required to help to deliver net zero will not happen in a vacuum. For instance, livelihoods and community cohesion may be put at risk as financial support is refocused on different land use practices and outcomes (Mills, 2012), while changing diets and import-export tariffs may radically alter demand and market prices in ways national governments cannot fully control (Hubbard et al., 2019; Willett et al., 2019).

Indeed, even addressing the physical issues of "leakage" in national emissions discussed earlier could have profound negative social impacts internationally. A more self-sufficient UK food system would, for example, mean reduced imports of food and fiber. This transition could certainly help to avoid the offshoring of emissions, but it may simultaneously undermine livelihoods overseas and so could hinder overseas development (Larch and Wanner, 2017; Böhringer et al., 2018).

\section{Society}

Achieving a just transition to net zero is arguably the most important aspect of all. Reductions in the land area used for agriculture are likely to be focussed on lower grade land, and so any negative impacts on livelihoods and communities may be magnified even further by the limited access to markets and infrastructure common to these areas (Ruben and Pender, 2004). As already highlighted, these local contexts and risks must be integrated into the design of any new support system, identifying the optimal change both from a physical basis and from a social basis (Feliciano et al., 2013).

High levels of engagement with and support from rural communities are required (Miller et al., 2009), again taking account of national circumstances and devolved powers. Regional land use strategies - as proposed in Scotland's Land Use Strategy (ScotGov., 2011)—could be a good starting point to address the inevitable synergies and antagonisms that arise from multiple land use objectives. They would need to be supported by improved data availability and an integrated decision support system that combines the physical and social realities at a locally relevant scale (Midgley et al., 2005). Such a system (drawing on an agent-based modeling or scenarios approach for instance; Brown and Castellazzi, 2014; Verburg et al., 2019) could be used to better identify risks and opportunities of differing support schemes and approaches. Flexibility within regional land use strategies would then help ensure that social and community priorities are better respected and could provide a dynamic structure through which national targets are kept on track.

Examinations of regional-scale approaches in Scotland have highlighted the importance of community engagement and acknowledgment of local contexts (Sutherland et al., 2011; Slee et al., 2014). This can be easier said than done of course-ideally there are existing community groups and structures that would facilitate such engagement (Rouillard et al., 2014), but this will vary from region to region and there is an inevitable trade-off between the benefits of fine scale applicability and the overheads of coordination and support required for this.

A governance system that allows effective flows of engagement and support from, say, individual landowner level, through community level, and up to local authority and regional scales would be required. Here, "regional boards" have been suggested whereby a diversity of stakeholders are represented from across the region and their representatives (or "trusted intermediaries" as they have been described for integrated catchment management; Rouillard and Spray, 2017) then provide a direct connection back to community and individual land owner levels.

Given the central role of local government in planning policy, individual (if very large) or multiple (if aligned to particular catchments for instance) local authorities might then have a formalized role in coordination of regional land use partnerships and in the design, implementation and reporting requirements of the regional frameworks that would underpin them. Such formal accountability is likely to be required to ensure sustainability of a land use strategy that must evolve in line with economy wide goals like net zero emissions. One risk is that such regional devolution of land use strategy would result in overall national divergence from a net zero pathway, so a dynamic feedback system for central government (e.g., modeled envelopes of land use change options and resulting emissions reductions for each region) would be required. Another major barrier is likely to be that of capacity within local authorities to effectively deliver this coordination and reporting role (Hislop et al., 2019). Addressing these issues will likely need both substantial capacity building within local government and additional financial support from central government.

\section{CONCLUSIONS}

More overt alignment of the agriculture and land use sectors with delivery of the Paris Climate Goals is inevitable. Whether the huge transitions required will be sustainable, just, and 
timely enough is far more questionable. An inherent risk is that emissions reduction objectives exert disproportionate pressures through food production systems, leading to unintended distortion of policies and markets, and ultimately to highly damaging failures.

The levels of integration required across governance, finance, skills, research and development, and social systems are daunting. The research community now has a vital role to play in supporting policy makers, farmers and all those involved in the land use sector to attain these high levels of integration.

Developed nations like the UK have a real opportunity to simultaneously deliver net zero emissions, secure the future of rural employment and enhance the myriad other "public goods" our land provides. Yes, realizing an effective system that can

\section{REFERENCES}

Alcalde, J., Smith, P., Haszeldine, R. S., and Bond, C. E. (2018). The potential for implementation of Negative Emission Technologies in Scotland. Int. J. Greenh. Gas Control 76, 85-91. doi: 10.1016/j.ijggc.2018.06.021

Allan, J., Donovan, C., Ekins, P., Gambhir, A., Hepburn, C., Reay, D., et al. (2020). A Net-Zero Emissions Economic Recovery From COVID-19. COP26. Universities Network Briefing.

Amon, B., Kryvoruchko, V., Amon, T., and Zechmeister-Boltenstern, S. (2006). Methane, nitrous oxide and ammonia emissions during storage and after application of dairy cattle slurry and influence of slurry treatment. Agric. Ecosyst. Environ. 112, 153-162. doi: 10.1016/j.agee.2005.08.030

Azar, C., Lindgren, K., Obersteiner, M., Riahi, K., van Vuuren, D. P., den Elzen, K. M. E. J., et al. (2010). The feasibility of low $\mathrm{CO}_{2}$ concentration targets and the role of bio-energy with carbon capture and storage (BECCS). Clim. Change 100, 195-202. doi: 10.1007/s10584-010-9832-7

Balafoutis, A., Beck, B., Fountas, S., Vangeyte, J., Van der Wal, T., Soto, I., et al. (2017). Precision agriculture technologies positively contributing to GHG emissions mitigation, farm productivity and economics. Sustainability 9:1339. doi: 10.3390/su9081339

Balmford, B., Green, R. E., Onial, M., Phalan, B., and Balmford, A. (2019). How imperfect can land sparing be before land sharing is more favourable for wild species? J. Appl. Ecol. 56, 73-84. doi: 10.1111/1365-2664.13282

Barnes, A., Schwarz, G., Keenleyside, C., Thomson, S., Waterhouse, T., Polokova, J., et al. (2011). Alternative Payment Approaches for Non-economic Farming Systems Delivering Environmental Public Goods. Report for UK Land Use Policy Group.

Bateman, I. J., and Balmford, B. (2018). Public funding for public goods: a postBrexit perspective on principles for agricultural policy. Land Use Policy 79, 293-300. doi: 10.1016/j.landusepol.2018.08.022

Böhringer, C., Carbone, J. C., and Rutherford, T. F. (2018). Embodied carbon tariffs. Scand. J. Econ. 120, 183-210. doi: 10.1111/sjoe.12211

Brown, I., and Castellazzi, M. (2014). Scenario analysis for regional decisionmaking on sustainable multifunctional land uses. Reg. Environ. Change 14, 1357-1371. doi: 10.1007/s10113-013-0579-3

Brown, I., Poggio, L., Gimona, A., and Castellazzi, M. (2011). Climate change, drought risk and land capability for agriculture: implications for land use in Scotland. Reg. Environ. Change 11, 503-518. doi: 10.1007/s10113-010-0163-z

Burton, V., Moseley, D., Brown, C., Metzger, M. J., and Bellamy, P. (2018). Reviewing the evidence base for the effects of woodland expansion on biodiversity and ecosystem services in the United Kingdom. For. Ecol. Manage. 430, 366-379. doi: 10.1016/j.foreco.2018.08.003

Bustamante, M., Robledo-Abad, C., Harper, R., Mbow, C., Ravindranat, N. H., and Sperling, F., et al. (2014). Co-benefits, trade-offs, barriers and policies for greenhouse gas mitigation in the agriculture, forestry and other land use (AFOLU) sector. Glob. Chang. Biol. 20, 3270-3290. doi: 10.1111/gcb. 12591 fully optimize agricultural support and land use decision-making across a whole nation is a huge undertaking, yet the potential pitfalls and missed opportunities of a "carbon blinkered" pathway to net zero are bigger still.

\section{AUTHOR CONTRIBUTIONS}

DR devised and wrote the manuscript.

\section{FUNDING}

DR was funded by the Natural Environment Research Council (NERC) Grant NE/S009019/1, as part of the Global Challenges Research Fund (GCRF) South Asia Nitrogen Hub (SANH).

Cayuela, M., Van Zwieten, L., Singh, B., Jeffery, S., Roig, A., and Sánchez Monedero, M. (2014). Biochar's role in mitigating soil nitrous oxide emissions: a review and meta-analysis. Agric. Ecosyst. Environ. 191, 5-16. doi: 10.1016/j.agee.2013.10.009

CCC (2019). Net Zero: The UK's Contribution to Stopping Global Warming, Committee on Climate Change. London.

CCC (2020). Land Use: Policies for a Net Zero UK, Committee on Climate Change. London.

Chhatre, A., Lakhanpal, S., Larson, A. M., Nelson, F., Ojha, H., and Rao, J. (2012). Social safeguards and co-benefits in REDD+: a review of the adjacent possible. Curr. Opin. Environ. Sustain. 4, 654-660. doi: 10.1016/j.cosust.2012.08.006

Churkina, G., Organschi, A., Reyer, C. P., Ruff, A., Vinke, K., Liu, Z., et al. (2020). Buildings as a global carbon sink. Nat. Sustain. 3, 269-276. doi: 10.1038/s41893-019-0462-4

Commission, F. (2019). Woodland Grant Scheme 3.

Crossman, N. D., Bryan, B. A., and Summers, D. M. (2011). Carbon payments and low-cost conservation. Conserv. Biol. 25, 835-845. doi: 10.1111/j.1523-1739.2011.01649.x

de Ruiter, H., Macdiarmid, J. I., Matthews, R. B., Kastner, T., and Smith, P. (2016). Global cropland and greenhouse gas impacts of UK food supply are increasingly located overseas. J. R. Soc. Interface 13:20151001. doi: 10.1098/rsif.2015.1001

Donnison, C., Holland, R., Hastings, A., Armstrong, L.-M., Eigenbrod, F., and Taylor, G. (2020). Bioenergy with Carbon Capture and Storage (BECCS): finding the win-win for energy, negative emissions, and ecosystem services-size matters. Global Change Biol. Bioenergy. doi: 10.1111/gcbb.12695. [Epub ahead of print].

Dooley, K., and Kartha, S. (2018). Land-based negative emissions: risks for climate mitigation and impacts on sustainable development. Int. Environ. Agreements Polit. Law Econ. 18, 79-98. doi: 10.1007/s10784-017-9382-9

Dupraz, P., and Guyomard, H. (2019). Environment and Climate in the common agricultural policy. EuroChoices 18, 18-25. doi: 10.1111/1746-692X.12219

Fajardy, M., and Mac Dowell, N. (2017). Can BECCS deliver sustainable and resource efficient negative emissions? Energy Environ. Sci. 10, 1389-1426. doi: 10.1039/C7EE00465F

Feliciano, D., Hunter, C., Slee, B., and Smith, P. (2013). Selecting land-based mitigation practices to reduce GHG emissions from the rural land use sector: a case study of North East Scotland. J. Environ. Manage. 120, 93-104. doi: 10.1016/j.jenvman.2013.02.010

Feliciano, D., Hunter, C., Slee, B., and Smith, P. (2014). Climate change mitigation options in the rural land use sector: Stakeholders' perspectives on barriers, enablers and the role of policy in North East Scotland. Environ. Sci. Policy 44, 26-38. doi: 10.1016/j.envsci.2014.07.010

Feliciano, D., Nayak, D. R., Vetter, S. H., and Hillier, J. (2017). CCAFS MOT-A tool for farmers, extension services and policy-advisors to identify mitigation options for agriculture. Agric. Syst. 154, 100-111. doi: 10.1016/j.agsy.2017.03.006 
Forster, E., Healey, J., Dymond, C., Newman, G., Davies, G., and Styles, D. (2019). Linking construction timber carbon storage with land use and forestry management practices. Proc. IOP Conf. Ser. Earth Environ. Sci. 323:012142. doi: 10.1088/1755-1315/323/1/012142

Garnett, T., Godde, C., Muller, A., Röös, E., Smith, P., de Boer, I. J. M., et al. (2017). Grazed and Confused? Ruminating on Cattle, Grazing Systems, Methane, Nitrous Oxide, the Soil Carbon Sequestration Question-and What It All Means for Greenhouse Gas Emissions. FCRN.

Gerber, P. J., Steinfeld, H., Henderson, B., Mottet, A., Opio, C., Dijkman, J., et al. (2013). Tackling Climate Change Through Livestock: A Global Assessment of Emissions and Mitigation Opportunities. Food and Agriculture Organization of the United Nations (FAO)

Government, U. K. (2019). Woodland Carbon Guarantee. Available online at: https://www.gov.uk/guidance/woodland-carbon-guarantee

Harper, A. B., Powell, T., Cox, P. M., House, J., Huntingford, C., Lenton, T. M., et al. (2018). Land-use emissions play a critical role in land-based mitigation for Paris climate targets. Nat. Commun. 9, 1-13. doi: 10.1038/s41467-018-05340-z

Helm, D., Mayer, C., Collins, C., Austen, M., Bateman, I., Leinster, P., et al. (2020). Advice on Using Nature Based Interventions to Reach Net Zero Greenhouse Gas Emissions by 2050. London: Natural Capital Committee.

Hislop, M., Scott, A. J., and Corbett, A. (2019). What does good green infrastructure planning policy look like? developing and testing a policy assessment tool within central Scotland UK. Plann. Theory Pract. 20, 633-655. doi: 10.1080/14649357.2019.1678667

Hubbard, C., Davis, J., Feng, S., Harvey, D., Liddon, A., Moxey, A., et al. (2019). Brexit: How Might UK Agriculture Thrive or Survive? Final report. Newcastle University, United Kingdom.

Kirschbaum, M. U. (2006). Temporary carbon sequestration cannot prevent climate change. Mitigat. Adapt. Strateg. Global Change 11, 1151-1164. doi: 10.1007/s11027-006-9027-8

Lamb, A., Green, R., Bateman, I., Broadmeadow, M., Bruce, T., Burney, J., et al. (2016). The potential for land sparing to offset greenhouse gas emissions from agriculture. Nat. Clim. Chang. 6:488. doi: 10.1038/nclimate2910

Lampkin, N., Smith, L., and Padel, K. (2019). Delivering on Net Zero. Scottish Agriculture.

Larch, M., and Wanner, J. (2017). Carbon tariffs: an analysis of the trade, welfare, and emission effects. J. Int. Econ. 109, 195-213. doi: 10.1016/j.jinteco.2017.09.003

Long, T. B., Blok, V., and Coninx, I. (2016). Barriers to the adoption and diffusion of technological innovations for climate-smart agriculture in Europe: evidence from the Netherlands, France, Switzerland and Italy. J. Clean. Prod. 112, 9-21. doi: 10.1016/j.jclepro.2015.06.044

Malone, B. P., Styc, Q., Minasny, B., and McBratney, A. B. (2017). Digital soil mapping of soil carbon at the farm scale: a spatial downscaling approach in consideration of measured and uncertain data. Geoderma 290, 91-99. doi: 10.1016/j.geoderma.2016.12.008

Matthews, A. (2013). Greening agricultural payments in the EU's common agricultural policy. Bio Based Appl. Econ. 2, 1-27.

McGregor, P. G., Swales, J. K., and Winning, M. A. (2012). A review of the role and remit of the committee on climate change. Energy Policy 41, 466-473. doi: 10.1016/j.enpol.2011.11.007

Midgley, J., Shucksmith, D., Birnie, R., Geddes, A., Bayfield, N., and Elston, D. (2005). Rural development policy and community data needs in Scotland. Land Use Policy 22, 163-174. doi: 10.1016/j.landusepol.2003. 08.007

Miller, D., Vogt, N., Nijnik, M., Brondizio, E., and Fiorini, S. (2009). “Integrating analytical and participatory techniques for planning the sustainable use of land resources and landscapes," in Planning Support Systems Best Practice and New Methods, Vol. 95. eds S. Geertman and J. Stillwell (Dordrecht: The GeoJournal Library; Springer), 317-345. doi: 10.1007/978-1-4020-8952-7_16

Mills, J. (2012). Exploring the social benefits of agri-environment schemes in England. J. Rural Stud. 28, 612-621. doi: 10.1016/j.jrurstud.2012. 08.001

Misselbrook, T., Hunt, J., Perazzolo, F., and Provolo, G. (2016). Greenhouse gas and ammonia emissions from slurry storage: Impacts of temperature and potential mitigation through covering (pig slurry) or acidification (cattle slurry). J. Environ. Qual. 45, 1520-1530. doi: 10.2134/jeq2015. 12.0618
Powlson, D. S., Stirling, C. M., Jat, M. L., Gerard, B. G., Palm, C. A., Sanchez, P. A., et al. (2014). Limited potential of no-till agriculture for climate change mitigation. Nat. Clim. Chang. 4, 678-683. doi: 10.1038/nclimate2292

Rayment, M. (2019). Paying for Public Goods From Land Management: How Much Will It Cost and How Might We Pay? Rayment Consulting Services Ltd.

Rodgers, C. (2019). Delivering a better natural environment? The Agriculture Bill and future agri-environment policy. Environ. Law Rev. 21, 38-48. doi: $10.1177 / 1461452918824504$

Rogelj, J., Popp, A., Calvin, K. V., Luderer, G., Emmerling, J., Gernaat, D., et al. (2018). Scenarios towards limiting global mean temperature increase below 1.5 C. Nat. Clim. Chang. 8:325. doi: 10.1038/s41558-018-0 091-3

Rose, D. C., Sutherland, W. J., Parker, C., Lobley, M., Winter, M., Morris, C., et al. (2016). Decision support tools for agriculture: towards effective design and delivery. Agric. Syst. 149, 165-174. doi: 10.1016/j.agsy.2016. 09.009

Rouillard, J., Reeves, A. D., Heal, K. V., and Ball, T. (2014). The role of public participation in encouraging changes in rural land use to reduce flood risk. Land Use Policy 38, 637-645. doi: 10.1016/j.landusepol.2014. 01.011

Rouillard, J. J., and Spray, C. J. (2017). Working across scales in integrated catchment management: lessons learned for adaptive water governance from regional experiences. Reg. Environ. Change 17, 1869-1880. doi: 10.1007/s10113-016-0988-1

Ruben, R., and Pender, J. (2004). Rural diversity and heterogeneity in lessfavoured areas: the quest for policy targeting. Food Policy 29, 303-320. doi: 10.1016/j.foodpol.2004.07.004

Sample, J. E., Baber, I., and Badger, R. (2016). A spatially distributed risk screening tool to assess climate and land use change impacts on water-related ecosystem services. Environ. Model. Softw. 83, 12-26. doi: 10.1016/j.envsoft.2016. 05.011

Schwarze, R., Niles, J. O., and Olander, J. (2002). Understanding and managing leakage in forest-based greenhouse-gas-mitigation projects. Philos. Transac. R. Soc. Lond. Ser. A Math. Phys. Eng. Sci. 360, 1685-1703. doi: $10.1098 /$ rsta.2002.1040

ScotGov. (2011). Getting the Best From Our Land: A Land Use Strategy for Scotland. Scottish Government Edinburgh.

Seddon, N., Chausson, A., Berry, P., Girardin, C. A. J., Smith, A., and Turner, B. (2020). Understanding the value and limits of nature-based solutions to climate change and other global challenges. Philos. Transac. R. Soc. B 375:20190120. doi: 10.1098/rstb.2019.0120

Slee, B., Brown, I., Donnelly, D., Gordon, I. J., Matthews, K., and Towers, W. (2014). The 'squeezed middle': identifying and addressing conflicting demands on intermediate quality farmland in Scotland. Land Use Policy 41, 206-216. doi: 10.1016/j.landusepol.2014.06.002

Smith, L. G., Kirk, G. J. D., Jones, P. J., and Williams, A. G. (2019). The greenhouse gas impacts of converting food production in England and Wales to organic methods. Nat. Commun. 10, 1-10. doi: 10.1038/s41467-019-1 2622-7

Smith, P., Soussana, J. F., Angers, D., Schipper, L., Chenu, C., Rasse, D. P., et al (2020). How to measure, report and verify soil carbon change to realize the potential of soil carbon sequestration for atmospheric greenhouse gas removal. Glob. Chang. Biol. 26, 219-241. doi: 10.1111/gcb.14815

Smith, R., Guevara, O., Wenzel, L., Dudley, N., Petrone-Mendoza, V., Cadena M., et al. (2019). "Ensuring Co-benefits for Biodiversity, Climate Change and Sustainable Development," in Handbook of Climate Change and Biodiversity. Climate Change Management, eds W. Leal Filho, J. Barbir, and R. Preziosi (Cham: Springer), 151-166. doi: 10.1007/978-3-319-98681-4_9

Soares, J. R., Cantarella, H., and de Campos Menegale, M. L. (2012). Ammonia volatilization losses from surface-applied urea with urease and nitrification inhibitors. Soil Biol. Biochem. 52, 82-89. doi: 10.1016/j.soilbio.2012. 04.019

Sutherland, L.-A., Barnes, A., McCrum, G., Blackstock, K., and Toma, L. (2011) Towards a cross-sectoral analysis of land use decision-making in Scotland. Landsc. Urban Plan. 100, 1-10. doi: 10.1016/j.landurbplan.2010.10.005

Tilman, D., and Clark, M. (2014). Global diets link environmental sustainability and human health. Nature 515:518. doi: 10.1038/nature 13959 
Verburg, P. H., Alexander, P., Evans, T., Magliocca, N. R., Malek, Z., Rounsevel, M. D. A., et al. (2019). Beyond land cover change: towards a new generation of land use models. Curr. Opin. Environ. Sustain. 38, 77-85. doi: 10.1016/j.cosust.2019.05.002

Vermeulen, S. J., Campbell, B. M., and Ingram, J. S. (2012). Climate change and food systems. Annu. Rev. Environ. Resour. 37, 195-222. doi: 10.1146/annurev-environ-020411-130608

Wall, E., Simm, G., and Moran, D. (2010). Developing breeding schemes to assist mitigation of greenhouse gas emissions. Animal 4, 366-376. doi: 10.1017/S175173110999070X

Willett, W., Rockström, J., Loken, B., Springmann, M., Lang, T., Vermeulen, S., et al. (2019). Food in the anthropocene: the EAT-Lancet Commission on healthy diets from sustainable food systems. Lancet 393, 447-492. doi: 10.1016/S0140-6736(18)31788-4
Wood, P. J., and Jotzo, F. (2011). Price floors for emissions trading. Energy Policy 39, 1746-1753. doi: 10.1016/j.enpol.2011.01.004

Conflict of Interest: The author declares that the research was conducted in the absence of any commercial or financial relationships that could be construed as a potential conflict of interest.

Copyright (c) 2020 Reay. This is an open-access article distributed under the terms of the Creative Commons Attribution License (CC BY). The use, distribution or reproduction in other forums is permitted, provided the original author(s) and the copyright owner(s) are credited and that the original publication in this journal is cited, in accordance with accepted academic practice. No use, distribution or reproduction is permitted which does not comply with these terms. 